\title{
SOME NEW ESTIMATES OF SHADOW ECONOMY FOR 80 COUNTRIES USING POOLED MEAN GROUP ESTIMATOR
}

\author{
Yan-Ling Tan \\ Universiti Teknologi MARA \\ Muzafar Shah Habibullah* \\ Universiti Putra Malaysia \\ Shivee Ranjanee Kaliappan \\ Universiti Putra Malaysia \\ Alias Radam \\ Universiti Putra Malaysia
}

\begin{abstract}
The purpose of this study is to estimates the size of the shadow economy for 80 countries from nine regions spanning the period 1975-2012 based on Tanzi-type currency demand approach (CDA). This study contributes to the literature in three distinct ways. First, we augment CDA regression with a macroeconomic uncertainty index (MUI). Second, the construction of the uncertainty index is based on the dynamic factor model (DFM). Third, the pooled mean group (PMG) estimator allows in capturing the heterogeneity across countries in the short-run dynamics but imposing restrictions in the long-run parameters. The results confirm the existence of the longrun equilibrium relationship among the variables examined. All coefficients show expected signs along with statistical significance. More importantly, the macroeconomic uncertainty index variable show positive relationship, suggesting that public tend to hold more currency in an uncertain macroeconomic environment. In addition, we observe that developing regions (ranging from $19.9 \%$ to $37.3 \%$ ) exhibit relatively large size of the shadow economy. On the contrary, developed regions have a considerable smaller estimate (ranging from $13.7 \%$ to $19.0 \%$ ) of the size of shadow economy. On average, the world estimate of the shadow economy as a percentage of GDP is about $23.1 \%$.
\end{abstract}

Keywords: Shadow Economy; Currency Demand; Macroeconomic Uncertainty; Pooled Mean Group.

\section{INTRODUCTION}

The aim of this study is to estimate the size of the shadow economy for 80 countries over the period 1975-2012 using the currency demand approach (CDA). The present study intends to contribute to the empirical literature in threefold. First, we highlight the need to incorporate a measure of macroeconomic uncertainty in computing the size of the shadow economy. The problem is that the impacts of macroeconomic uncertainty are not

*Corresponding author: Faculty of Economics and Management, Universiti Putra Malaysia, 43400 UPM Serdang, Selangor, Malaysia. Tel: +603 89467635 Email: muzafar@upm.edu.my 
limited to the formal economy, but also extended to the shadow economy. It is argued that individuals tend to participate in the shadow economy in the period of economic hardship by under reporting their actual income as households are uncertain of the future income levels; by improving their personal finances in order to compensate for lost income (Schneider \& Kearney, 2013); and by increasing their precautionary saving balances by holding more currency.

Second, we modelled the macroeconomic uncertainty index by means of dynamic factor model. To reflect uncertainty about macroeconomic conditions, an array of indicators consisting of real GDP per capita, interest rate, total tax revenue to GDP ratio, inflation rate, and exchange rate were used to construct the index. As opposed to other quantitative measures, the macroeconomic uncertainty index is designed to be a better measure with greater coverage of a macroeconomic perspective. Factor models can deal with various variables without lack of degrees of freedom that usually encountered in regression analysis. Moreover, the idiosyncratic movements which contain measurement error and local shocks can be eliminated, yielding a more reliable signal for policy makers.

Third, we use the pooled mean group (PMG) estimator proposed by Pesaran et al. (1999) to examine the long-run relationships between currency demand and its other determinants for the nine regions, namely; East Asia and Pacific (EAP), Europe and Central Asia (ECA), Latin America and the Caribbean (LAC), Middle East and North, Africa (MENA), South Asia (SAS), Sub-Saharan Africa (SSA), high income OECD, high income non-OECD, and euro area (EURO) regions This estimator has advantage over the standard estimators since it allows the heterogeneity across countries in the short-run dynamics but imposes homogeneity restrictions in the long-run coefficients. However, empirical studies using larger panel (for instance, Alm and Embaye, 2013; Elgin and Oztunali, 2012 and Schneider et al., 2010) estimated the shadow economy without considering the heterogeneity across countries. In the case of panel data the estimation of the size of the shadow economy should be carried out by accounting for cross-country heterogeneity.

This is because each region has its own characteristics and dynamics, especially concerning the differences of tax policies and socio-economic characteristics. For instance, based on the estimates of the size of shadow economy by Schneider et al. (2010), Latin America and the Caribbean (LAC), Sub-Saharan Africa (SSA), and Europe and Central Asia (ECA) have the largest estimates at $41.1 \%, 40.2 \%$, and $38.8 \%$ and the OECD (high income) countries have the smallest size of about $17.1 \%$, indicating that there is great heterogeneity between regions. More specifically, each region is also characterized by considerable heterogeneity where the size of the shadow economy in LAC (the largest share of the shadow economy) varies from $25.3 \%$ in Argentina to $66.1 \%$ in Bolivia; while in high income OECD countries the size of the shadow economy ranges from the lowest of $8.5 \%$ in Switzerland to $27.2 \%$ in Poland.

The paper is organized as follows. In the next section we discuss the currency demand model use to estimate the size of the shadow economy. In section 3, we discuss the pooled mean group estimator used to estimates the currency demand model. In section 4, we discuss the empirical results. The last section contains our conclusion. 


\section{LITERATURE REVIEW}

\subsection{The currency demand model approach (CDA)}

The currency demand approach (CDA) is considered as one of the most well-recognized and popular methods in estimating the size of the shadow economy. Table 1 shows that there have been increasing empirical literature estimating the size of the shadow economy using the CDA method. Basically, CDA is based on the idea of Cagan (1958) and was later extended by Tanzi (1983) who incorporated an econometric estimation on currency demand equation for the United States economy from 1930-1980. The idea behind this approach assumes that shadow economy transactions are undertaken in the form of cash which leave no trace. Transactions involving cash are difficult to trace as compared to those activities using other assets or registered in any financial institutions. For example, a rise in the tax burden implies stronger incentive to engage in cash-intensive underground economic activities, and hence increase the demand for cash. In other words, the CDA provides an indirect measure of the shadow economy by estimating how much cash used for shadow transactions with assumption about the equality of velocity between the cash used in the unofficial and the official economy (Tanzi, 2002).

Since currency in circulation is a subset of the money demand, thus, the currency demand is modelled as a function of a scale variable (often measured by real income) to account for transactions demand, the opportunity cost of holding currency (represented by interest rate), and additional variables that might influence the behaviour of currency holdings. Based on the theoretical arguments from standard demand approaches, macroeconomic uncertainty, therefore, may affect the demand for currency in two ways. We follow Özdemir and Saygili $(2013$, p.317) by interpreting macroeconomic uncertainty "as the periods that are characterized by increased negative sentiments of economic agents regarding the state of the economy. Hence, pessimism about the economy is considered to be the heightened periods of economic uncertainty". In such environment, economic agents become more uncertain and pessimistic about the future economic activities. This would cause investors and businessmen to lose confidence (Özdemir \& Saygili, 2013) which induces public to take a precautionary measure by holding more cash, and increases the shadow economic activities. But, there is another effect where macroeconomic uncertainty can affect people to lost trust and confidence in government policies by switching the liquidity preference to hold more saver assets instead of increasing their cash holding, and reduces the size of the shadow economy. We then argue that currency ratio is sensitive to the macroeconomic uncertainty measure. The role of macroeconomic uncertainty in estimating the size of the shadow economy may even be more important than its role under money demand models as both uncertainty and shadow economy estimates are unobservable. Therefore, there are serious consequences for ignoring the uncertainty measure in the estimation of the CDA, which is also similar to those problems arise in estimating money demand functions.

Motivated by the augmented money demand function and following Tanzi (1983) and other subsequent studies (Alm, 2012; Bajada, 1999; Dell'Anno \& Halicioglu, 2010), the augmented CDA function incorporating the macroeconomic uncertainty index (MUI) in a panel setting can be specify as: 


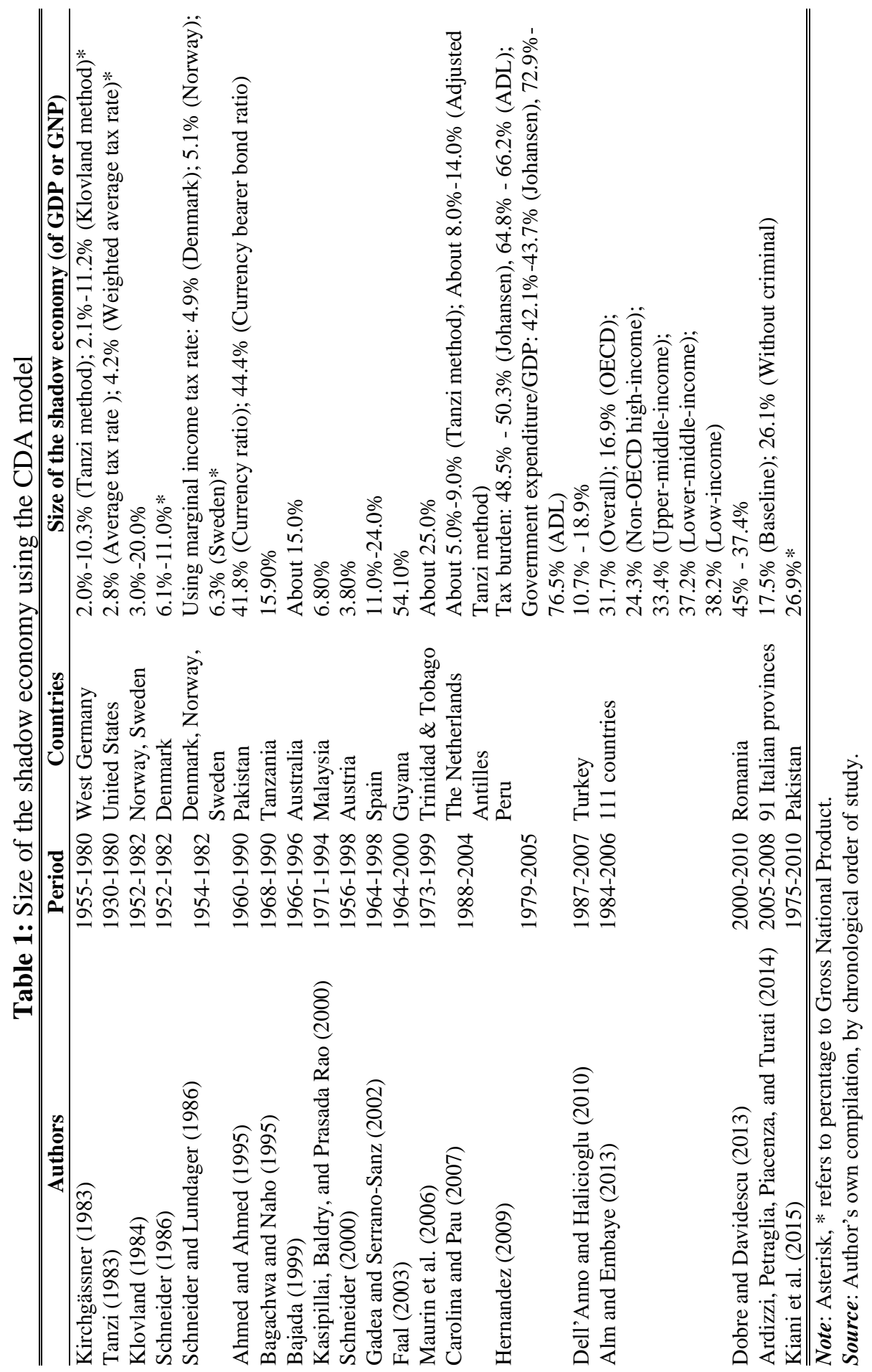


$\ln \left(\frac{\mathrm{C}}{\mathrm{M} 2}\right)_{\mathrm{it}}=\theta_{0}+\theta_{1} \ln (\mathrm{TAX})_{\mathrm{it}}+\theta_{2} \ln (\mathrm{R})_{\mathrm{it}}+\theta_{3} \ln (\mathrm{YPC})_{\mathrm{it}}+\theta_{4} \ln (\mathrm{MUI})_{\mathrm{it}}+\mu_{\mathrm{it}}(1)$

where $i, t$ denote for country $i$ in year $t, \frac{C}{\mathrm{M} 2}$ is the ratio of currency in circulation to broad money supply $\left(\mathrm{M}_{2}\right)$, TAX is the average tax rate, $\mathrm{R}$ is the real interest rate, YPC is the real per capita income, MUI is the macroeconomic uncertainty index, and $\mu$ is the error term.

As noted by Cagan (1958), as income rises, the demand for deposits increases because services of deposits are more safer than holding currency. Hence, the level of economic development is expected to be inversely related to the shadow economic activities by replacing the currency holdings with checks which in turn, leading to a decline in currency ratio. Thus, the estimated coefficient for $\theta_{1}$ is expected to be positive while the parameter estimates for real interest rate $\left(\theta_{2}\right)$ and income per capita $\left(\theta_{3}\right)$ are expected to be negatively related with currency holdings. On the one hand, the precautionary demand for currency arises when uncertainty is high; while on the other hand, a rise in the macroeconomic uncertainty causes people to hold less currency due to substitution effect. Therefore, there is no clear sign for the MUI coefficient, $\left(\theta_{4}\right)$.

\subsection{Measuring macroeconomic uncertainty index}

There is a wide range of methods available for constructing the uncertainty measures. This study adopts the dynamic factor model (DFM) to construct MUI for each country. This is because DFM method has some major advantages over other methods (Breitung \& Eickmeier, 2006). Due to limited data availability and low-frequency observations (annual observations), we consider several potential indicators namely economic activity (real GDP per capita), monetary policy (interest rate), fiscal policy (total tax revenue to GDP ratio), inflation rate, and exchange rate that could reflect uncertainty about macroeconomic conditions. A higher value of this index implies that the macroeconomic environment is more uncertain and volatile. Basically, the DFM is applied to model multivariate time series as linear function of unobserved factors and disturbances. The unobserved factors may follow a vector autoregressive structure. Based on Stock and Watson (1998), a standard DFM has the following form:

$\mathrm{Y}_{\mathrm{t}}=\mathrm{Pf}_{\mathrm{t}}+\varepsilon_{\mathrm{t}}$

$\mathrm{f}_{\mathrm{t}}=\mathrm{A}_{1} \mathrm{f}_{\mathrm{t}-1}+\mathrm{A}_{2} \mathrm{f}_{\mathrm{t}-2}+\cdots+\mathrm{A}_{\mathrm{t}-\mathrm{q}} \mathrm{f}_{\mathrm{t}-\mathrm{q}}+\mu_{\mathrm{t}}$

where $Y_{t}$ is a $(k \times 1)$ vector of dependent variables, $P$ is a $\left(k \times n_{f}\right)$ matrix of parameters (factor loadings), $\mathrm{f}_{\mathrm{t}}$ is a $\left(\mathrm{n}_{\mathrm{f}} \times 1\right)$ vector of unobservable factors, $\varepsilon_{\mathrm{t}}$ is a $(\mathrm{k} \times 1)$ vector of disturbances, $A_{i}$ is a $\left(n_{f} \times n_{f}\right)$ matrix of autocorrelation parameters, and $\mu_{t}$ is a $(k \times 1)$ vector of idiosyncratic disturbances.

In the next step, we formulate the DFM for each country in each region as follow:

$\mathrm{Y}_{\mathrm{jt}}=\mathrm{P}_{\mathrm{j}} \mathrm{f}_{\mathrm{t}}+\varepsilon_{\mathrm{jt}}$

$\mathrm{f}_{\mathrm{t}}=\mathrm{A}_{1} \mathrm{f}_{\mathrm{t}-1}+\mathrm{A}_{2} \mathrm{f}_{\mathrm{t}-2}+\cdots+\mathrm{A}_{\mathrm{t}-\mathrm{q}} \mathrm{f}_{\mathrm{t}-\mathrm{q}}+\mu_{\mathrm{t}}$ 
where $\mathrm{j}=1,2, \ldots, \mathrm{N}$ indexed for countries in each region ${ }^{1}, \mathrm{Y}_{\mathrm{jt}}$ is a $\left(\mathrm{k}_{\mathrm{j}} \times 1\right)$ vector of dependent variables of country $j^{2}, P_{j}$ is a $\left(k_{j} \times n_{f}\right)$ matrix of parameters (factor loadings), $\mathrm{f}_{\mathrm{t}}$ is a $\left(\mathrm{n}_{\mathrm{f}} \times 1\right)$ vector of unobservable factors, $\varepsilon_{\mathrm{jt}}$ is a $\left(\mathrm{k}_{\mathrm{j}} \times 1\right)$ vector of disturbances, $A_{i}$ is a $\left(n_{f} \times n_{f}\right)$ matrix of autocorrelation parameters, and $\mu_{t}$ is a $(k \times 1)$ vector of idiosyncratic disturbances. We model their demeaned variables as linear function of an unobserved factor that follows a first-order autoregressive, AR(1) process ${ }^{3}$. The parameters of DFM were estimated using maximum likelihood (ML). $\mathrm{f}_{\mathrm{t}}$ is estimated as a MUI to measure the macroeconomic uncertainty conditions of each country.

\section{METHODOLOGY}

We use the pooled mean group estimator (PMG) proposed by Pesaran et al. (1999) to formulate the dynamic heterogeneous panel models. The PMG estimator allows the intercept, short-run coefficients and error variance to be varied across groups, but imposes homogeneity restrictions on the long-run coefficients over the cross-section ${ }^{4}$. For example, by specifying a ARDL $(1,1,1,1,1)$ in a panel setting, we have:

$$
\begin{gathered}
\ln \left(\frac{\mathrm{C}}{\mathrm{M} 2}\right)_{\mathrm{it}}=\mu_{0}+\sum_{\mathrm{j}=1}^{\mathrm{p}} \lambda_{\mathrm{j}} \ln \left(\frac{\mathrm{C}}{\mathrm{M} 2}\right)_{\mathrm{i}, \mathrm{t}-\mathrm{j}}+\sum_{\mathrm{j}=0}^{\mathrm{q}} \delta_{1 \mathrm{j}} \ln (\mathrm{TAX})_{\mathrm{i}, \mathrm{t}-\mathrm{j}}+\sum_{\mathrm{j}=0}^{\mathrm{q}} \delta_{2 \mathrm{j}} \ln (\mathrm{R})_{\mathrm{i}, \mathrm{t}-\mathrm{j}} \\
+\sum_{\mathrm{j}=0}^{\mathrm{q}} \delta_{3 \mathrm{j}} \ln (\mathrm{YPC})_{\mathrm{i}, \mathrm{t}-\mathrm{j}}+\sum_{\mathrm{j}=0}^{\mathrm{q}} \delta_{4 \mathrm{j}} \ln (\mathrm{MUI})_{\mathrm{i}, \mathrm{t}-\mathrm{j}}+\varepsilon_{i t}
\end{gathered}
$$

where $\mathrm{i}=1, \ldots, \mathrm{N} ; \mathrm{t}=1, \ldots, \mathrm{T}$. In refers to natural logarithm, $\frac{\mathrm{C}}{\mathrm{M} 2}$ is currency in circulation to broad money supply $\left(\mathrm{M}_{2}\right)$ ratio, TAX is the average tax rate $(\%), \mathrm{R}$ is the real interest paid on saving deposits (\%), YPC is the real income per capita (US\$), MUI is the macroeconomic uncertainty index, and $\varepsilon$ is the error term. The long-run model as per Equation (1) can be derived when; $\theta_{0}=\left(\frac{\mu_{0}}{1-\lambda_{\mathrm{j}}}\right)$ is the constant term, $\theta_{1}=\left(\frac{\delta_{10}+\delta_{11}}{1-\lambda_{\mathrm{j}}}\right), \theta_{2}=$ $\left(\frac{\delta_{20}+\delta_{21}}{1-\lambda_{\mathrm{j}}}\right), \theta_{3}=\left(\frac{\delta_{30}+\delta_{31}}{1-\lambda_{\mathrm{j}}}\right)$, and $\theta_{4}=\left(\frac{\delta_{40}+\delta_{41}}{1-\lambda_{\mathrm{j}}}\right)$ are the long-run coefficients.

The short-run model or the error-correction equation can be defined as follow:

$$
\begin{aligned}
& \Delta \ln \left(\frac{\mathrm{C}}{\mathrm{M} 2}\right)_{\mathrm{it}}=\alpha+\phi \mathrm{ECT}_{\mathrm{t}-1}+\delta_{10 \mathrm{i}} \Delta \ln (\mathrm{TAX})_{\mathrm{it}}+\delta_{20 \mathrm{i}} \Delta \ln (\mathrm{R})_{\mathrm{it}}+\delta_{30 \mathrm{i}} \Delta \ln (\mathrm{YPC})_{\mathrm{it}} \\
& +\delta_{40 \mathrm{i}} \Delta \ln (\mathrm{MUI})_{\mathrm{it}}+\omega_{\mathrm{it}}
\end{aligned}
$$

\footnotetext{
${ }^{1}$ For instance, $\mathrm{j}=1,2, \ldots, 11$ for EAP, SSA, high income OECD, and EURO, $\mathrm{j}=1,2, \ldots, 9$ for LAC, $\mathrm{j}=$ $1,2, \ldots, 8$ for ECA and high income non-OECD, $\mathrm{j}=1,2, \ldots, 6$ for LAC, and $\mathrm{j}=1,2, \ldots, 5$ for SAS.

${ }^{2}$ Macroeconomic indicators for each country, and the details are provided in Appendix B.

${ }^{3}$ Data transformation also form part of initial preparation of data before data analysis. In doing so we take the first-difference of each variable and then the demeaned variables are obtained by subtracting the mean and dividing by the standard deviation.

${ }^{4}$ As claimed by Pesaran et al. (1999), the reason behind the expecting of the common long-run equilibrium relationships across countries because of budget or solvency constraints, arbitrage conditions, or common technologies that could affect all countries in the same way.
} 
where $\phi=-\left(1-\lambda_{\mathrm{j}}\right)$, is the error-correction speed of adjustment, and the errorcorrection term (ECT) is derived by $\ln \left(\frac{\mathrm{C}}{\mathrm{M} 2}\right)_{\mathrm{i}, \mathrm{t}-1}-\theta_{0}-\theta_{1} \ln (\mathrm{TAX})_{\mathrm{i}, \mathrm{t}-1}-$ $\theta_{2} \ln (\mathrm{R})_{\mathrm{i}, \mathrm{t}-1}-\theta_{3} \ln (\mathrm{YPC})_{\mathrm{i}, \mathrm{t}-1}-\theta_{4} \ln (\mathrm{MUI})_{\mathrm{i}, \mathrm{t}-1}$.

A significant and negative value of $\phi$ implies the existence of long-run relationship or cointegration. The PMG restriction is that the elements of long-run coefficients are common across countries. To calculate the shadow economy, we follow Tanzi (1983) and other studies in several steps. First, we calculate the predicted value of currency ratio, expressed as $\mathrm{Z}_{\mathrm{it}}^{*}=\ln \left(\frac{\mathrm{C}}{\mathrm{M} 2}\right)_{\mathrm{it}}^{*}$ using Equation (7). The second step involves calculating the predicted value of currency ratio by setting the tax rate at zero, whilst the estimated coefficients for other variables remain unchanged, denoted as $\mathrm{Z}_{\mathrm{it}}=\ln \left(\frac{\mathrm{C}}{\mathrm{M} 2}\right)_{\mathrm{it}}$. Third, the difference between $\mathrm{C}_{\mathrm{it}}^{*}$ and $\mathrm{C}_{\mathrm{it}}$ shows an estimate of illegal stock money (stock of currency held for the purpose of tax evasion). Fourth, the illegal stock money is multiplied by the velocity of money, to yield an estimate of shadow economy. It is assumed that velocity of illegal stock money is equal to the velocity of legal money. Lastly, the shadow economy as a percentage of the official economy (\% of GDP) is expressed for the purpose of comparison, by computing the amount of shadow economy divided by GDP.

\subsection{Data and descriptions of variables}

The data are at annual frequency, consisting of 80 countries for the period 1975 - 2012. According to the World Bank country classification, these countries are classified as East Asia and Pacific (EAP), Europe and Central Asia (ECA), Latin America and the Caribbean (LAC), Middle East and North, Africa (MENA), South Asia (SAS), SubSaharan Africa (SSA), high income OECD, high income non-OECD, and euro area (EURO) regions ${ }^{5}$. The length and width of panel is constrained by the lack of available data on variables capturing tax burden. In addition, the constructed panel data set has been left unbalanced in order to increase the sample size. Data for currency in circulation, and M2 are drawn from Asian Development Bank's (ADB) Website (http://www.adb.org) and International Financial Statistics (IFS) 2013 CD-Rom. Data for tax revenue is collected from ADB, World Bank's World Development Indicators (WDI), Government Finance Statistics (GFS) 2014 CD-Rom. Due to issue of data unavailability, in some instance, we use different measures of interest rates from different sources including deposit rate and money market rate (IFS) and discount rate (Datastream). Other data such as income per capita, inflation rate and exchange rate are collected from World Bank's World Development Indicators (WDI). In Appendix A, we outline the countries and their sample

\footnotetext{
${ }^{5} \mathrm{We}$ extract the Eurozone, the official euro area, from high income OECD and high income non-OECD regions. The reason that the euro area is an economic and monetary union (EMU) consisting of 19 European Union (EU) member states which have adopted their single currency namely euro currency. It currently consists of Austria, Belgium, Cyprus, Estonia, Finland, France, Germany, Greece, Ireland, Italy, Latvia, Luxembourg, Malta, Netherlands, Portugal, Slovak Republic, Slovenia and Spain. The information is obtained from https://www.ecb.europa.eu/euro/intro/html/map.en.html.
} 
periods in the panel and Appendix B contains detailed descriptions of each variable and data source used in this study.

\section{RESULTS AND DISCUSSIONS}

\subsection{Panel unit root tests}

Prior to the estimations, we evaluate the integration properties of all the variables used in the analysis. The panel unit root tests employed are widely used first generation panel unit root tests allowing for an unbalanced panel dataset (Im, Pesaran, \& Shin, 2003; Maddala $\& \mathrm{Wu}, 1999)$. All the tests are based on the null of a unit root. We find strong evidence that most variables are clearly I $(1)$ if a length of two or more lags are used. The only exception is the macroeconomic economic uncertainty (LnMUI) which is found to be stationary at levels for all regions. This is because LnMUI is constructed using the dynamic factor model (DFM) that requires its variables to be stationary at the first place. Study by Elbadawi, Kaltani and Schmidt-Hebbel (2008) confirmed that all variables examined are stationary if they are formulated as index numbers, trend deviations, or shares. Overall, these results suggest most conservatively that all series in levels are nonstationary $\mathrm{I}(1)$ except LnMUI which is found to be $\mathrm{I}(0)$. Therefore, it may worth noting that none of the variables examined are I(2) or higher level of integration ${ }^{6}$.

\subsection{Pooled mean group (PMG) estimator}

Table 2 reports the estimation results for the PMG estimator. PMG estimator is based on an autoregressive distributed lag (ARDL) model which does not require the variables to be $\mathrm{I}(1)$ and still valid whether variables of interest are $\mathrm{I}(0)$ and $\mathrm{I}(1)$. Hence, the PMG estimator avoids the need of pretesting for unit root. Furthermore, the PMG estimates will be more consistent and efficient under several specification conditions. First condition is related to the residuals of the error-correction model. The preferred ARDL models are augmented with more lags to ensure that the regression residuals are serially uncorrelated and in turn, the independent variables can be treated as exogenous. In doing so, we choose the lag length criteria using AIC and SBC while the maximum lag order of the ARDL model is set for three for each country.

The second condition requires the adjustment coefficients to be negative and within the unit circle, which implies that there exists a long-run relationship (dynamic stability). As shown in Table 2, all the error-correction coefficients are significantly negative and fall within the dynamically stable range, revealing that the dynamic stability condition holds. Hence, this can be treated as evidence in supporting for cointegration relationship that indeed exists among the variables ${ }^{7}$. In terms of the adjustment coefficients (which is measured in absolute values), there is considerable cross regional variation, with EAP having the lowest of 0.182 and SSA, the highest of 0.414 . Meanwhile, the average speed of adjustment coefficients for high income OECD, high income non-OECD, and EURO

\footnotetext{
${ }^{6}$ To conserve space the results for panel unit root tests are available from the authors upon request.

${ }^{7}$ The null hypothesis of non-cointegration can be tested using the error-correction $t$-statistics. If the null is not rejected, we conclude that there is no cointegration between variables (or vice versa).
} 


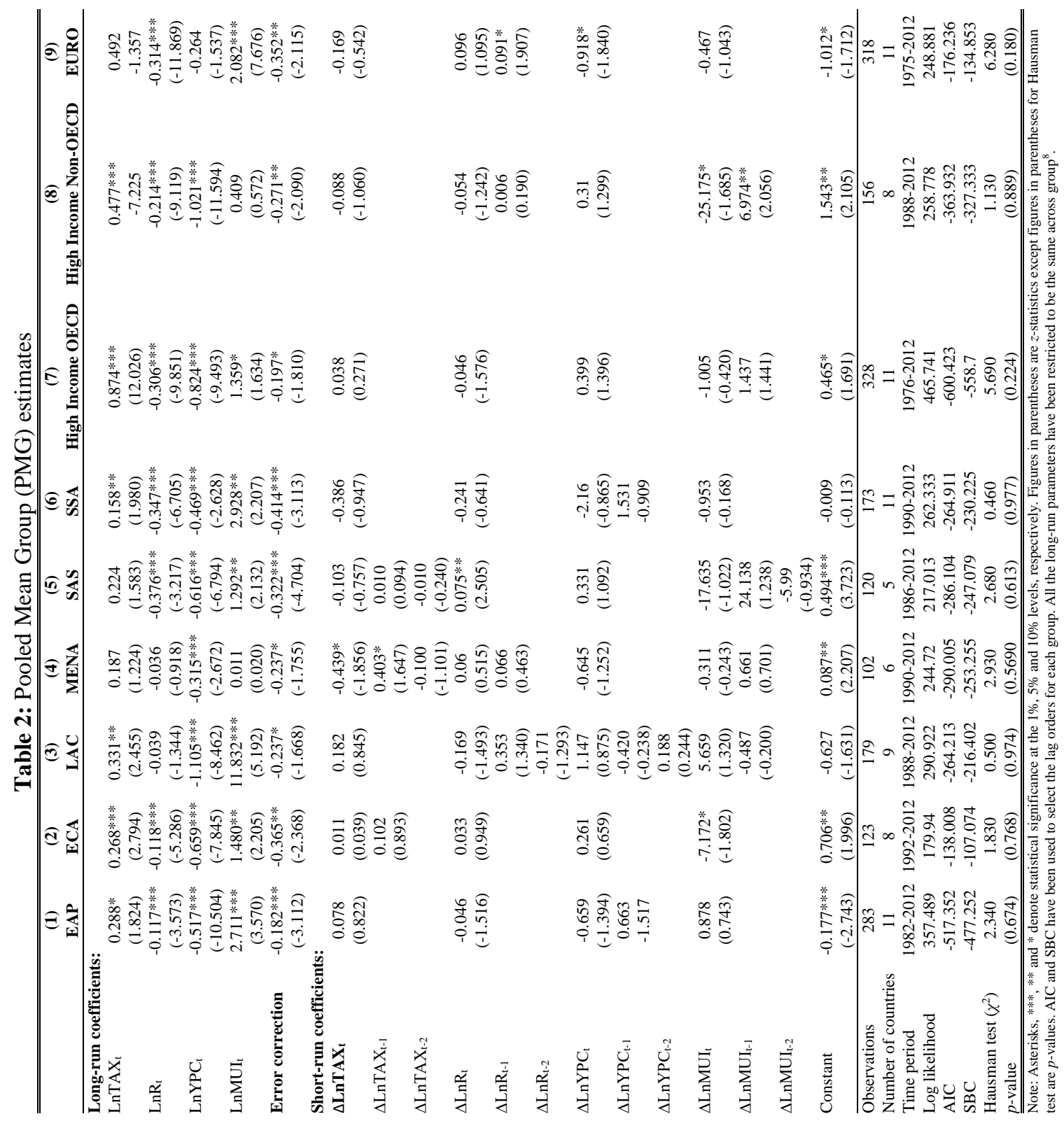

${ }^{8}$ According to Pesaran et al. (1999), the PMG estimates are more preferable to the MG estimates in terms of their better precision and less sensitive to outlier estimates. Moreover, numerous dynamic panel data studies have focused on the magnitude of large $\mathrm{T}$ and small N. Like previous studies such as Asteriou (2009) $(\mathrm{N}=5$; $\mathrm{T}=1975-2002$ ), Camarero (2008) (different $\mathrm{N}$ ranging from 5 to $12 ; \mathrm{T}=1970-1998$ ), Das and Chowdhury (2011) ( $\mathrm{N}=11 ; \mathrm{T}=1985-2009)$, Pesaran et al., (1999) (a. $\mathrm{N}=24 ; \mathrm{T}=1962-1993$, b. $\mathrm{N}=10 ; \mathrm{T}=1974-1990)$, and Santana-Gallego, Ledesma-Rodríguez, and Pérez-Rodríguez, (2011) (N=5; T=1980-2006). Similarly, we also focus on relatively smaller $\mathrm{N}$, ranging from 6 to 11 with moderate to large $\mathrm{T}$ in this study. 
regions are $0.197,0.271$, and 0.352 , respectively. There are some noteworthy differences across nine regions; in some instances adjustment is considerably slow. For example, SSA region appears somehow faster while EAP shows relatively slower adjustment process. These slow adjustments support the view of Wong (1977) on money demand that the speed of adjustment to equilibrium in LDCs may be slow if most wealth holders are risk averters. The slowness could arise due to risk averters are more conservative in adjusting their portfolios when confronted with higher risks and uncertainties. In addition, the halflife of deviations from equilibrium is about two to four years range. The third condition refers to the long-run coefficients are identical across countries. As regards to the PMG and MG estimations, the Hausman tests indicate that imposing long-run homogeneity cannot be rejected at the conventional significance levels in all regions. For that reason, the PMG estimation is the appropriate ones for subsequent interpretations. Therefore, the rest of the study relies on the PMG estimator.

The long-run parameter estimates can be discussed as follows. In line with the economic expectation, the estimated coefficients of all the long-run models from column (1) to column (9) have the expected signs. The long-run coefficients of the average tax rate (LnTAX) are positive and significant in most regions except MENA, SAS, and EURO, signifying that economic agents who wish to avoid taxes tend to use more currency. Thus, rising tax burden discourage work and push more people into the shadow economy. In addition, the significant and negative long-run parameter estimates on income per capita (LnYPC) in all countries, suggesting that greater economic prosperity lowers currency demand. Perhaps as people get richer they attempt to evade less. As for the long-run effects of other determinants, the coefficients of the real interest rate (LnR) carry negative sign and highly significant at least at the 5\% levels in most regions except LAC and MENA. This is consistent with the evidence of the previous studies that interest rate equals the opportunity cost of holding currency (Alm \& Embaye, 2013; Ardizzi et al., 2014; Bagachwa \& Naho, 1995; Hill \& Kabir, 2000). A rise in interest rate leads to an increase in the opportunity cost of holding currency causing people to demand less currency holding.

Turning back to the initial motivation of the study, our main concern is the introduction of macroeconomic uncertainty index (LnMUI) in the CDA model. It is clear that macroeconomic uncertainty index carries a positive and significant coefficient in all regions with the exception of MENA and high income non-OECD regions, implying that indeed a worsening macroeconomic environment has a positive long-run effect on the currency demand in all regions. This is because economic agents might take a precautionary action towards more safer and liquid assets and hence lead to a rise in the currency ratio. These significant and positive estimates are similar to several studies on the demand for money such as Arize (1987), Atta-Mensah (2004), Bahmani-Oskooee et al. (2013), Bahmani-Oskooee and Xi (2011), Choi and Oh (2003), and Greiber and Lemke (2005). On the other hand, uncertain macroeconomic condition causes a greater nervousness and anxiety that may make agents to reduce trust level through distorting their ability of paying taxes and hence increase the shadow economic activities.

Lastly, the PMG estimator allows the short-run coefficients to be different across countries. However, the contemporaneous changes tell an entirely different story, where all the short-run coefficients for average tax rate (LnTAX), real interest rate (LnR), 
income per capita (LnYPC), and macroeconomic uncertainty index (LnMUI) appears to be insignificant. This shows that in the short-run these coefficients are not important determinants of currency ratio, suggesting all determinants have more permanent effects (movements) than transitory effects in all regions over the sample period.

\subsection{The size of the shadow economies}

We estimate the size of the shadow economy for 80 countries over the period 1975-2012 using the estimated results from Table 2 combined with the procedures we discussed earlier. However, the PMG estimator involves the testing for cointegration using the standard ARDL model for panels which requires different lag orders. Therefore, we consider the time period 1978-2012 and the complete dataset containing a list of the shadow economy estimates for 80 countries is reported in Appendix C.

Table 3 presents these estimates with the purpose of observing the variation of the size of the shadow economy according to different regions. We observe that developing regions (ranging from $19.9 \%$ to $37.3 \%$ ) exhibit relatively larger size of the shadow economy. In particular, ECA and MENA have reached a sizeable figure of the shadow economy, 37.3\% and $31.3 \%$, respectively. The estimates are closely followed by EAP (27.4\%), SAS $(23.7 \%)$, SSA (22.5\%), and LAC (19.9\%). On the other hand, developed regions have a considerable smaller estimate (ranging from $13.7 \%$ to $19.0 \%$ ) where the shadow economy estimates for EURO (13.7\%) are still small in comparison to both high income OECD and high income non-OECD countries (19.0\%). In terms of the standard deviations, there is a wide difference between regions. Overall, the world estimates of the shadow economy as a percentage of GDP, on average, is about $23.1 \%$ (standard deviation of $13.5 \%$ ).

Table 3: Descriptive statistics for shadow economy (\% of GDP)

\begin{tabular}{lccccc}
\hline \hline & Mean & Std. Dev. & Median & Min & Max \\
\hline EAP & 27.4 & 14.9 & 24.9 & 14.0 & 66.0 \\
ECA & 37.3 & 19.6 & 29.0 & 12.9 & 69.6 \\
LAC & 19.9 & 5.5 & 16.9 & 15.3 & 31.2 \\
MENA & 31.3 & 18.1 & 23.3 & 16.6 & 63.1 \\
SAS & 23.7 & 13.9 & 23.1 & 11.3 & 44.9 \\
SSA & 22.5 & 6.4 & 19.5 & 16.3 & 37.2 \\
High Income OECD & 19.0 & 12.9 & 16.4 & 6.7 & 48.6 \\
High Income Non-OECD & 19.0 & 10.9 & 16.7 & 5.9 & 36.0 \\
EURO & 13.7 & 6.7 & 12.0 & 6.2 & 30.2 \\
World & 23.1 & 13.5 & 19.0 & 5.9 & 69.6 \\
\hline \hline
\end{tabular}

Source: Authors' own calculations

Next Figure 1 illustrates the development of the size of the shadow economy by different regions over time. The upper panel of the figure shows the evolution of the shadow economy for developing regions, while the evolution of the estimates in the developed regions is given in the lower panel. As observed, the shadow economy estimates have been fluctuating around $15-40 \%$ for most developing regions except EAP, ECA, and LAC. Nevertheless, EAP and LAC seem to have a slightly declining trend over the entire sample period. On the contrary, we observe that the shadow economy in ECA skyrocketed to reach its peak point in 1998 with more than $50 \%$ of economic activities are 
underground, and it remain quite stable in subsequent two years before declining. Developed regions (lower panel), on the other hand, have experienced significant changes over the sample period. Initially, we observe an upward trend during the period 19781997, followed by a dramatic decline between 1998 and 2007, and starts climbing from 2008 onwards.

Figure 1: Trend of shadow economy (\% of GDP) over time by regions

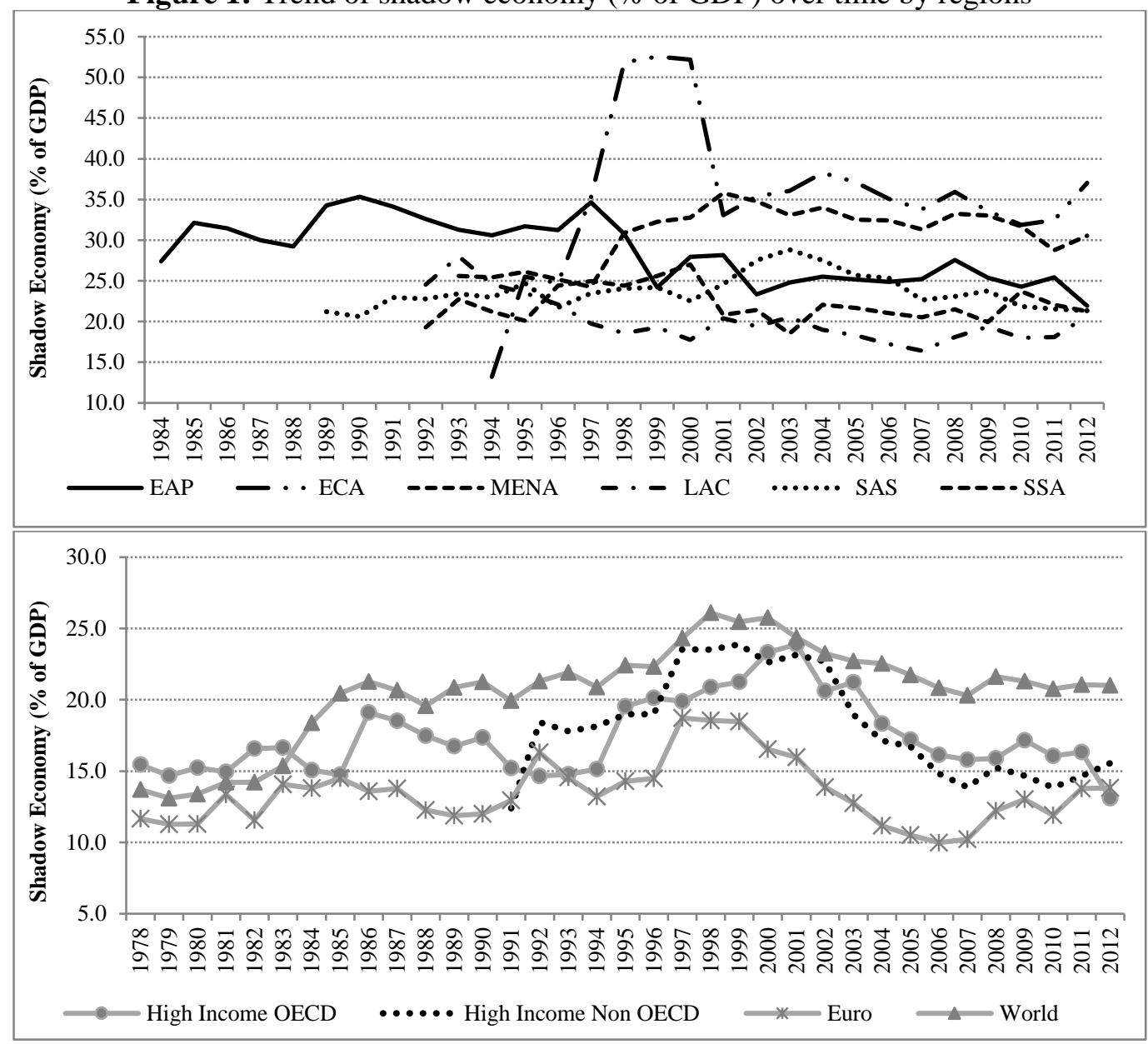

Source: Authors' own computation.

Lastly, Figure 2 demonstrates how large the variation in the size of the shadow economy as a portion of GDP. The top position is largely occupied by most of the developing countries such as Thailand, Kyrgyz Republic, Egypt, Moldova, Jordan, Bangladesh and Republic of Korea. These countries have a relatively large share of the shadow economy between $41-70 \%$ (of GDP), showing that the shadow economy is more than half the size of the official economy. Notice that the advanced countries are located at the bottom of the figure, with an average of about 5-15\% (of GDP). These countries include Bahrain, 
Figure 2: Distribution of the size of the shadow economy (\% of GDP)

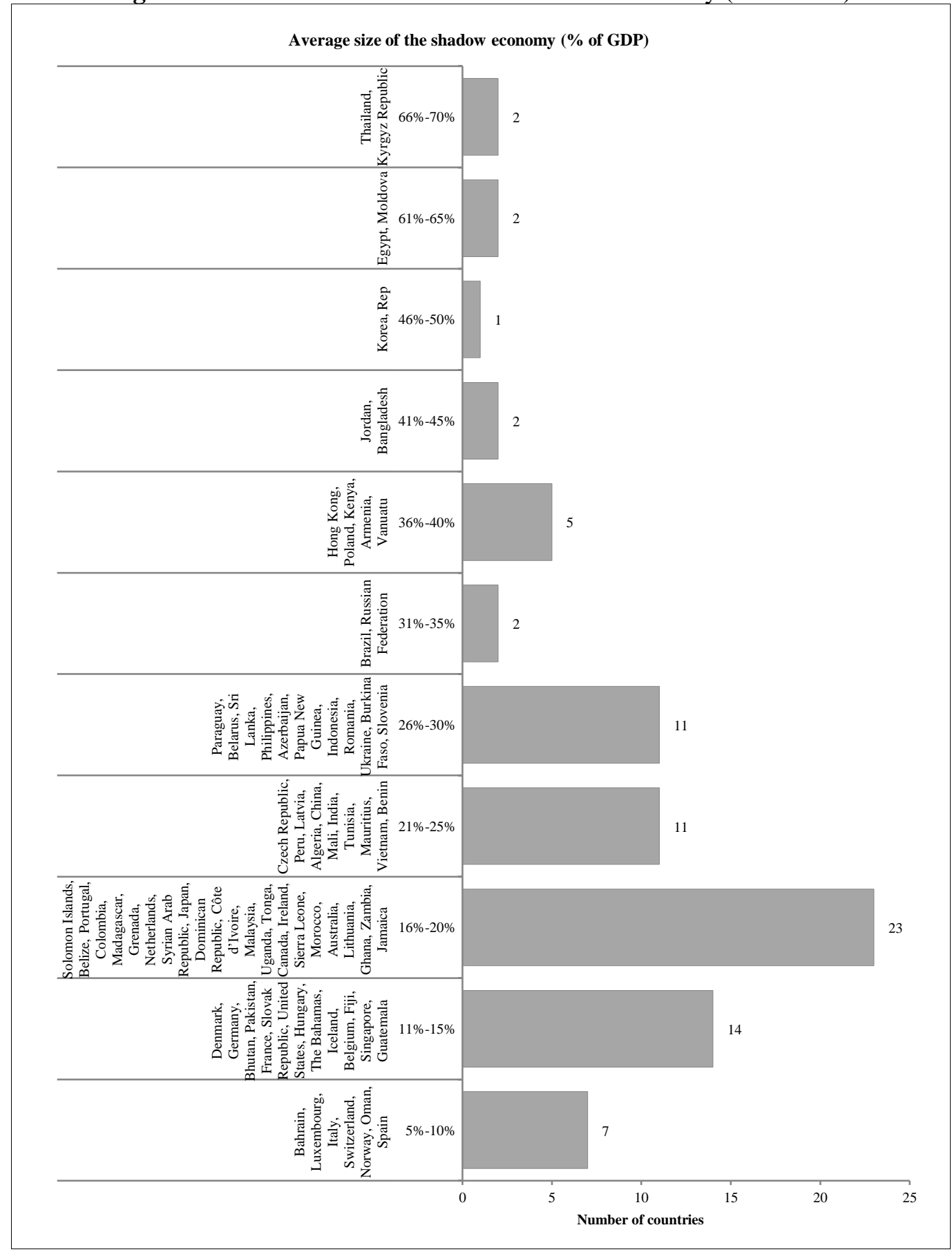

Source: Author's own calculations 
Luxembourg, Italy, Switzerland, Norway, Oman, Spain, Denmark, Germany, Bhutan, Pakistan, France, Slovak Republic, United States, Hungary, The Bahamas, Iceland, Belgium, Fiji, Singapore, and Guatemala. Overall, we find that most countries are situated in the middle where average shadow economies lie between 16\%-20\% (of GDP). These countries are Solomon Islands, Belize, Portugal, Colombia, Madagascar, Grenada, Netherlands, Syrian Arab Republic, Japan, Dominican Republic, Côte d'Ivoire, Malaysia, Uganda, Tonga, Canada, Ireland, Sierra Leone, Morocco, Australia, Lithuania, Ghana, Zambia, and Jamaica.

\section{CONCLUSION}

There are a large number of cash transactions that are typically taking place outside the control of the government authorities every year. In most general form, these activities are known as shadow economy. The existence of the shadow economy tends to misrepresent the true size of a country's economy. Therefore, the aim of this study is to estimate the size of the shadow economy for 80 countries from nine regions over the period 1975-2012 using the currency demand approach. In this study, we go beyond the existing studies by introducing a measure of macroeconomic uncertainty index (MUI) in the standard CDA model. Second, we model the MUI for each country by means of dynamic factor model (DFM). Third, the PMG estimator allows capturing the heterogeneity across countries in the short-run dynamics but imposing restrictions in the long-run parameters. Once such an estimation results are specified, we use the resulting parameters to compute the size of the shadow economy for 80 countries. Thus, our study allows heterogeneity across countries by estimating a sub-regional panel data setting as compared to a large panel setting as was done by Alm \& Embaye (2013), Elgin \& Oztunali (2012), Schneider et al. (2010) and Schneider (2007) ${ }^{9}$,

The empirical findings indicate the existence of long-run relationship among variables examined. In terms of the adjustment coefficients (which is measured in absolute values), there is considerable cross regional variation, with the lowest of 0.182 and the highest of 0.414 . This suggests that on average approximately $18.2 \%$ to $41.4 \%$ of the deviations of currency ratio from the long-run equilibrium are corrected during one year. In addition, most long-run coefficients are statistically significant and have the expected signs. We find that in the long-run, an increase of the tax rate can increase the use of currency ratio. In contrast, higher interest rate tends to lower the currency demand by increasing the opportunity cost of holding currency. Similarly, high levels of economic activity leading to a significantly lower currency ratio. Turning to our variable of interest, the currency demand is positively influenced by macroeconomic uncertainty. Such an uncertain macroeconomic environment tends to encourage people to hold more currency.

Subsequently, the estimated long-run coefficients of the CDA equations are adopted to calculate the size of the shadow economy. We observe that developing regions (ranging

\footnotetext{
${ }^{9}$ Schneider et al. (2010) and Elgin and Oztunali (2012) have constructed the world's largest dataset on 162 and 161 countries, respectively. However, the former has covered a relatively short period of time from 19992007, while the latter on an unbalanced dataset from 1950-2009. On the other hand, Alm \& Embaye (2013) estimate unbalanced panel of 111 countries together with a long time period from 1984-2006.
} 
from $19.9 \%$ to $37.3 \%$ ) exhibit relatively larger size of the shadow economy. Alternatively, developed regions have a considerable smaller estimate (ranging from $13.7 \%$ to $19.0 \%$ ) where the shadow economy estimates for Euro area (13.7\%) are still small in comparison to both high income OECD and high income non OECD countries (19.0\%). Additionally, it is noticed that the size of the shadow economy has fluctuated substantially in most regions over the sample period. For the initial period, there has been an upward trend in the shadow economy; however, it falls continuously until 2007-2008 before increasing again. On average, the estimated world shadow economy as a percentage of GDP is about $23.1 \%$.

\section{REFERENCES}

Ahmed, M., \& Ahmed, Q. M. (1995). Estimation of the black economy of Pakistan through the monetary approach. The Pakistan Development Review, 34(4), 791-807.

Alm, J. (2012). Measuring, explaining, and controlling tax evasion: Lessons from theory, experiments, and field studies. International Tax and Public Finance, 19(1), 54-77.

Alm, J., \& Embaye, A. (2013). Using dynamic panel methods to estimate shadow economies around the world, 1984-2006. Public Finance Review, 41(5), 510-543.

Ardizzi, G., Petraglia, C., Piacenza, M., \& Turati, G. (2014). Measuring the underground economy with the currency demand approach: A reinterpretation of the methodology, with an application to Italy. Review of Income and Wealth, 60(1), $747-772$.

Arize, A. C. (1987). Past inflation variability and the stability of the demand-for-money function in Nigeria. Atlantic Economic Journal, 15(1), 31-41.

Asteriou, D. (2009). Foreign aid and economic growth: New evidence from a panel data approach for five South Asian countries. Journal of Policy Modeling, 31(1), 155-161.

Atta-Mensah, J. (2004). Money demand and economic uncertainty. Bank of Canada Working Paper No.2004-25. Ontario: Bank of Canada.

Bagachwa, M. S. D., \& Naho, A. (1995). Estimating the second economy in Tanzania. World Development, 23(8), 1387-1399.

Bahmani-Oskooee, M., \& Xi, D. (2011). Economic uncertainty, monetary uncertainty and the demand for money in Australia. Australian Economic Papers, 50(4), 115-128.

Bahmani-Oskooee, M., Kutan, A. M., \& Xi, D. (2013). The impact of economic and monetary uncertainty on the demand for money in emerging economies. Applied Economics, 45(23), 3278-3287.

Bajada, C. (1999). Estimates of the underground economy in Australia. Economic Record, 75(4), 369-384.

Breitung, J., \& Eickmeier, S. (2006). Dynamic factor models. Allgemeines Statistisches Archiv, 90(1), 27-42.

Cagan, P. (1958). The demand for currency relative to the total money supply. Journal of Political Economy, 66(4), 303-328.

Camarero, M. (2008). The real exchange rate of the dollar for a panel of OECD countries: Balassa-Samuelson or distribution sector effect? Journal of Comparative Economics, 36(4), 620-632.

Carolina, M. G. L., \& Pau, L. (2007). The shadow economy in the Netherlands Antilles. Social and Economic Studies, 56(4), 46-81. 
Choi, W. G., \& Oh, S. (2003). A money demand function with output uncertainty, monetary uncertainty, and financial innovations. Journal of Money, Credit and Banking, 35(5), 685-709.

Das, A., \& Chowdhury, M. (2011). Remittances and GDP dynamics in 11 developing countries: Evidence from panel cointegration and PMG techniques. Romanian Economic Journal, 14(42), 3-23.

Dell'Anno, R., \& Halicioglu, F. (2010). An ARDL model of unrecorded and recorded economies in Turkey. Journal of Economic Studies, 37(6), 627-646.

Dobre, I., \& Davidescu, A. A. (2013). Long-run demand for money and the size of shadow economy in Romania: An application of ARDL model. Economic Computation and Economic Cybernetics Studies and Research, 47(3), 91-109.

Elbadawi, I. A., Kaltani, L., \& Schmidt-Hebbel, K. (2008). Foreign aid, the real exchange rate, and economic growth in the aftermath of civil wars. The World Bank Economic Review, 22(1), 113-140.

Elgin, C., \& Oztunali, O. (2012). Shadow economies around the world: Model based estimates. Working Papers No.2012/5. Istanbul: Bogazici University, Department of Economics.

Faal, E. (2003). Currency demand, the underground economy, and tax evasion: The case of Guyana. IMF Working Papers No.WP/03/7.

Gadea, M. D., \& Serrano-Sanz, J. M. (2002). The hidden economy in Spain - A monetary estimation, 1964-1998. Empirical Economics, 27(3), 499-527.

Greiber, C., \& Lemke, W. (2005). Money demand and macroeconomic uncertainty. Volkswirtschaftliches Forschungszentrum der Deutschen Bundesbank Discussion Paper Series 1 No.2005/26.

Hernandez, M. A. (2009). Estimating the size of the hidden economy in Peru: A currency demand approach. Revista de Ciencias Empresariales Y Economia, 8(1), 85-104.

Hill, R., \& Kabir, M. (2000). Currency demand and the growth of the underground economy in Canada, 1991-1995. Applied Economics, 32(2), 183-192.

Im, K. S., Pesaran, M. H., \& Shin, Y. (2003). Testing for unit roots in heterogeneous panels. Journal of Econometrics, 115(1), 53-74.

Kasipillai, J., Baldry, J., \& Prasada Rao, D. S. (2000). Estimating the size and determinants of hidden income and tax evasion in Malaysia. Asian Review of Accounting, 8(2), 25-42.

Kiani, M., Ahmed, A., \& Zaman, K. (2015). Combining qualitative and quantitative approaches for measuring underground economy of Pakistan. Quality \& Quantity, $49(1), 295-317$.

Kirchgässner, G. (1983). Size and development of the West German shadow economy, 1955-1980. Zeitschrift Für Die Gesamte Staatswissenschaft/Journal of Institutional and Theoretical Economics, 139(2), 197-214.

Klovland, J. T. (1984). Tax evasion and the demand for currency in Norway and Sweden. Is there a hidden relationship? The Scandinavian Journal of Economics, 86(4), 423-439.

Maddala, G. S., \& Wu, S. (1999). A comparative study of unit root tests with panel data and a new simple test. Oxford Bulletin of Economics and Statistics, 61(S1), 631-652.

Maurin, A., Sookram, S., \& Watson, P. K. (2006). Measuring the size of the hidden economy in Trinidad \& Tobago, 1973-1999. International Economic Journal, 20(3), 321-341. 
Özdemir, K. A., \& Saygili, M. (2013). Economic uncertainty and money demand stability in Turkey. Journal of Economic Studies, 40(3), 314-333.

Pesaran, M. H., Shin, Y., \& Smith, R. P. (1999). Pooled mean group estimation of dynamic heterogeneous panels. Journal of the American Statistical Association, 94(446), 621-634.

Santana-Gallego, M., Ledesma-Rodríguez, F., \& Pérez-Rodríguez, J. (2011). Tourism and trade in OECD countries. A dynamic heterogeneous panel data analysis. Empirical Economics, 41(2), 533-554.

Schneider, F. (1986). Estimating the size of the Danish shadow economy using the currency demand approach: An attempt. The Scandinavian Journal of Economics, $88(4), 643-668$.

Schneider, F. (2000). The growth of the shadow economy in the OECD: Some preliminary explanations. Journal of International Affairs, 53(2), 413-431.

Schneider, F. (2007). Shadow economies and corruption all over the world: New estimates for 145 countries. Economics: The Open-Access, Open-Assessment EJournal No. 2007-9.

Schneider, F., \& Kearney, A. T. (2013). The shadow economy in Europe, 2013. Johannes Kepler Universitat Linz.

Schneider, F., \& Lundager, J. (1986). The development of the shadow economies for Denmark, Norway, and Sweden: A comparison. European Journal of Political Economy, 2(3), 351-394.

Schneider, F., Buehn, A., \& Montenegro, C. E. (2010). New estimates for the shadow economies all over the world. International Economic Journal, 24(4), 443-461.

Stock, J. H., \& Watson, M. W. (1998). Diffusion indexes. NBER Working Paper 6702.

Tanzi, V. (1983). The underground economy in the United States: Annual estimates, 1930-80 (L'économie clandestine aux Etats-Unis: estimations annuelles, 1930-80) (La "economía subterránea" de Estados Unidos: Estimaciones anuales, 1930-80). Staff Papers - International Monetary Fund, 30(2), 283-305.

Tanzi, V. (2002). The shadow economy, its causes and its consequences. In International Seminar on the Shadow Economy Index in Brazil. Rio de Janeiro: Brazilian Institute for Ethics in Competition (ETCO).

Wong, C. (1977). Demand for money in developing countries. Journal of Monetary Economics, 3(1), 59-86. 


\section{APPENDICES}

Appendix A: Lists of countries by regions

\begin{tabular}{ll}
\hline \hline \multicolumn{1}{c}{ Regions } & \multicolumn{1}{c}{ Countries } \\
\hline EAP & $\begin{array}{l}\text { China, Fiji, Indonesia, Malaysia, Papua New Guinea, } \\
\text { Philippines, Solomon Is, Thailand, Tonga, Vanuatu, Vietnam }\end{array}$ \\
\hline ECA & $\begin{array}{l}\text { Armenia, Azerbaijan, Belarus, Hungary, Kyrgyz Rep, Moldova, } \\
\text { Romania, Ukraine }\end{array}$ \\
\hline LAC & $\begin{array}{l}\text { Belize, Brazil, Colombia, Dominican Rep, Grenada, Guatemala, } \\
\text { Jamaica, Paraguay, Peru }\end{array}$ \\
\hline MENA & Algeria, Egypt, Jordan, Morocco, Syria, Tunisia \\
\hline SAS & Bangladesh, Bhutan, India, Pakistan, Sri Lanka \\
\hline SSA & $\begin{array}{l}\text { Benin, Burkina Faso, Cote d'Ivoire, Ghana, Kenya, Madagascar, } \\
\text { Mali, Mauritius, Sierra Leone, Uganda, Zambia }\end{array}$ \\
\hline High income OECD & $\begin{array}{l}\text { Australia, Canada, Czech Rep, Denmark, Iceland, Japan, South } \\
\text { Korea, Norway, Poland, Switzerland, United States }\end{array}$ \\
\hline High income non-OECD & $\begin{array}{l}\text { Bahamas, Bahrain, Hong Kong, Latvia, Lithuania, Oman, } \\
\text { Russian Fed, Singapore }\end{array}$ \\
\hline EURO & $\begin{array}{l}\text { Belgium, France, Germany, Ireland, Italy, Luxembourg, } \\
\text { Netherlands, Portugal, Slovak Rep, Slovenia, Spain }\end{array}$ \\
\hline \hline
\end{tabular}

Appendix B: Variable descriptions and data sources

\begin{tabular}{|c|c|c|}
\hline Variables & Description/Definition & Sources \\
\hline $\mathrm{C} / \mathrm{M} 2$ & $\begin{array}{l}\text { Ratio of currency in circulation to M2. } \\
\text { Currency in circulation comprises currency } \\
\text { with the public, refers specifically to coins } \\
\text { and notes outside the banking system, and } \\
\text { M2 comprises money and quasi money. }\end{array}$ & $\begin{array}{l}\text { Currency in circulation, M1 and M2 are } \\
\text { drawn from Asian Development Bank } \\
\text { (ADB) and International Financial Statistics } \\
\text { (IFS). M1 is used to calculate the velocity. }\end{array}$ \\
\hline TAX & $\begin{array}{l}\text { Total tax revenues divided by GDP (annual } \\
\%) \text {. }\end{array}$ & $\begin{array}{l}\text { Total tax revenues are from ADB, World } \\
\text { Bank, and Government Finance Statistics } \\
\text { (GFS) whereas GDP is collected from } \\
\text { World Bank. }\end{array}$ \\
\hline $\mathrm{R}$ & $\begin{array}{l}\text { Real interest rate from different measures } \\
\text { include deposit rate, money market rate, } \\
\text { money market rate (annual \%); inflation rate } \\
\text { measured by GDP deflator (annual \%). }\end{array}$ & $\begin{array}{l}\text { Deposit rate and money market rate } \\
\text { (IFS); Discount rate (Datastream). }\end{array}$ \\
\hline YPC & GDP per capita at constant 2005 (US\$). & World Bank. \\
\hline MUI & $\begin{array}{l}\text { Macroeconomic uncertainty index is } \\
\text { constructed based five main macroeconomic } \\
\text { indicators namely total tax revenue to GDP } \\
\text { ratio, different measures of interest rate } \\
\text { include deposit rate, money market rate, } \\
\text { money market rate (annual \%), GDP per } \\
\text { capita at constant } 2005 \text { (US\$), inflation rate } \\
\text { measured by GDP deflator (annual \%), and } \\
\text { exchange rate. }\end{array}$ & $\begin{array}{l}\text { Nearly all of the variables listed as in above } \\
\text { sources except inflation rate is obtained } \\
\text { from World Bank. }\end{array}$ \\
\hline
\end{tabular}




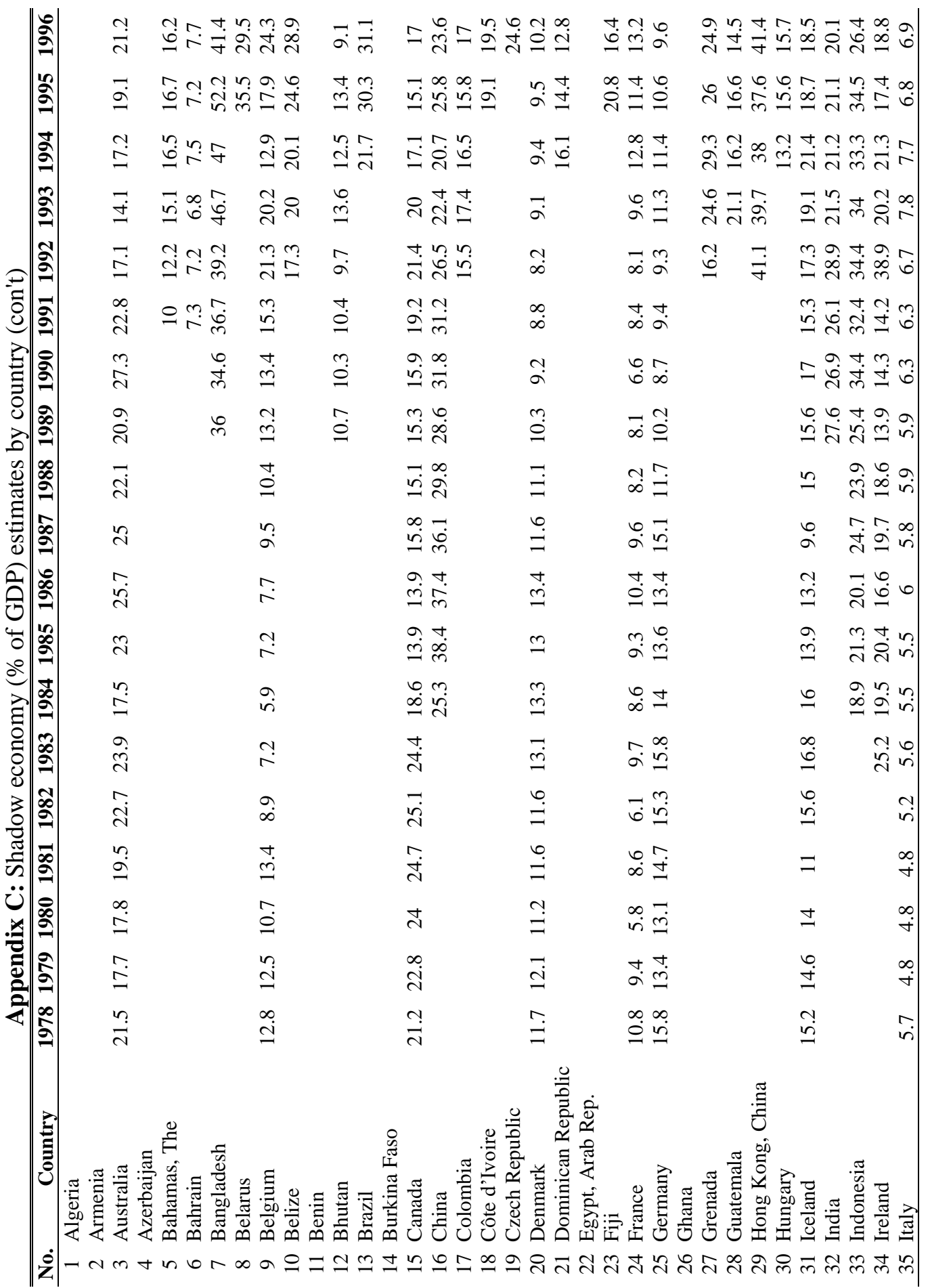




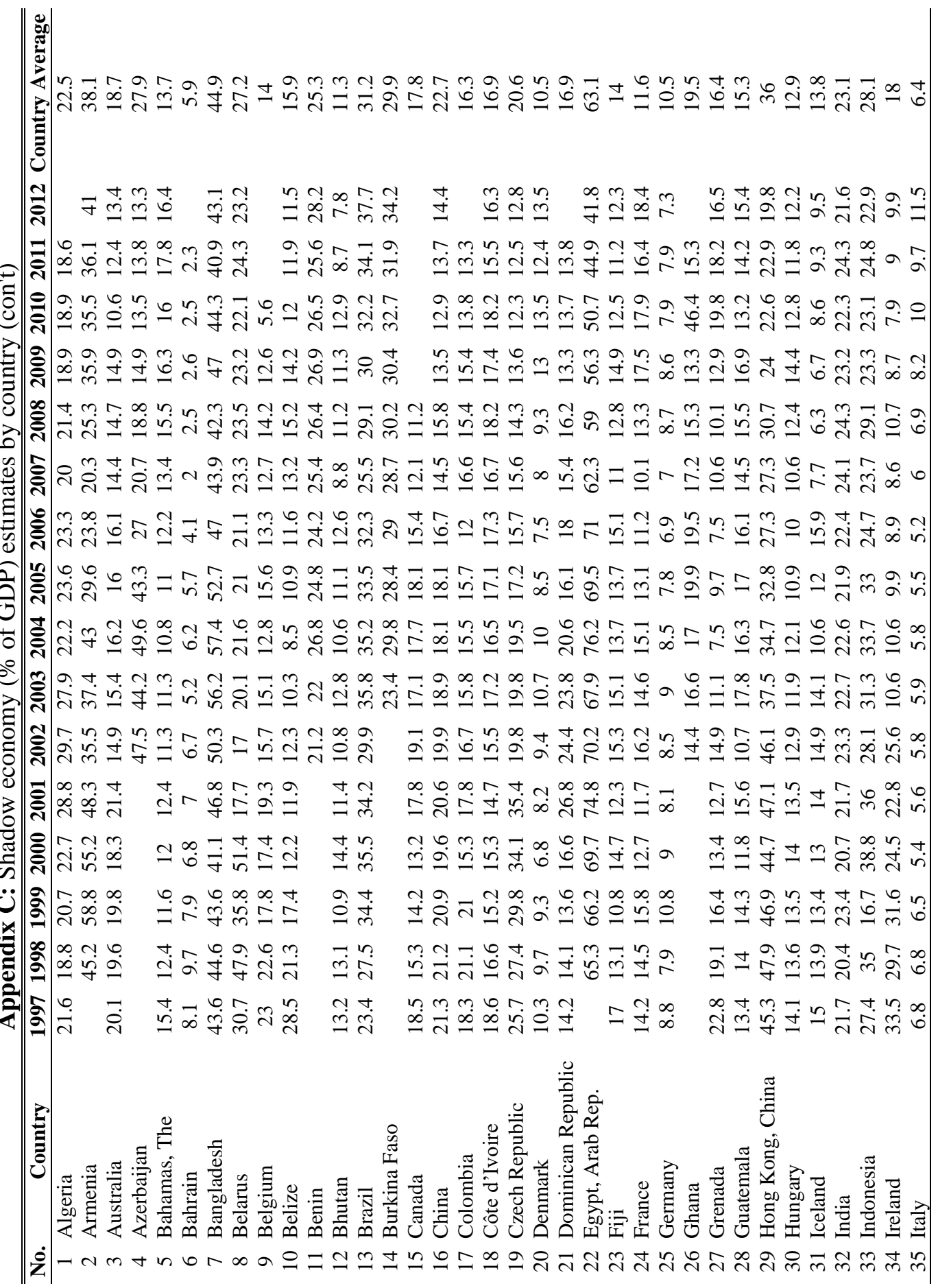




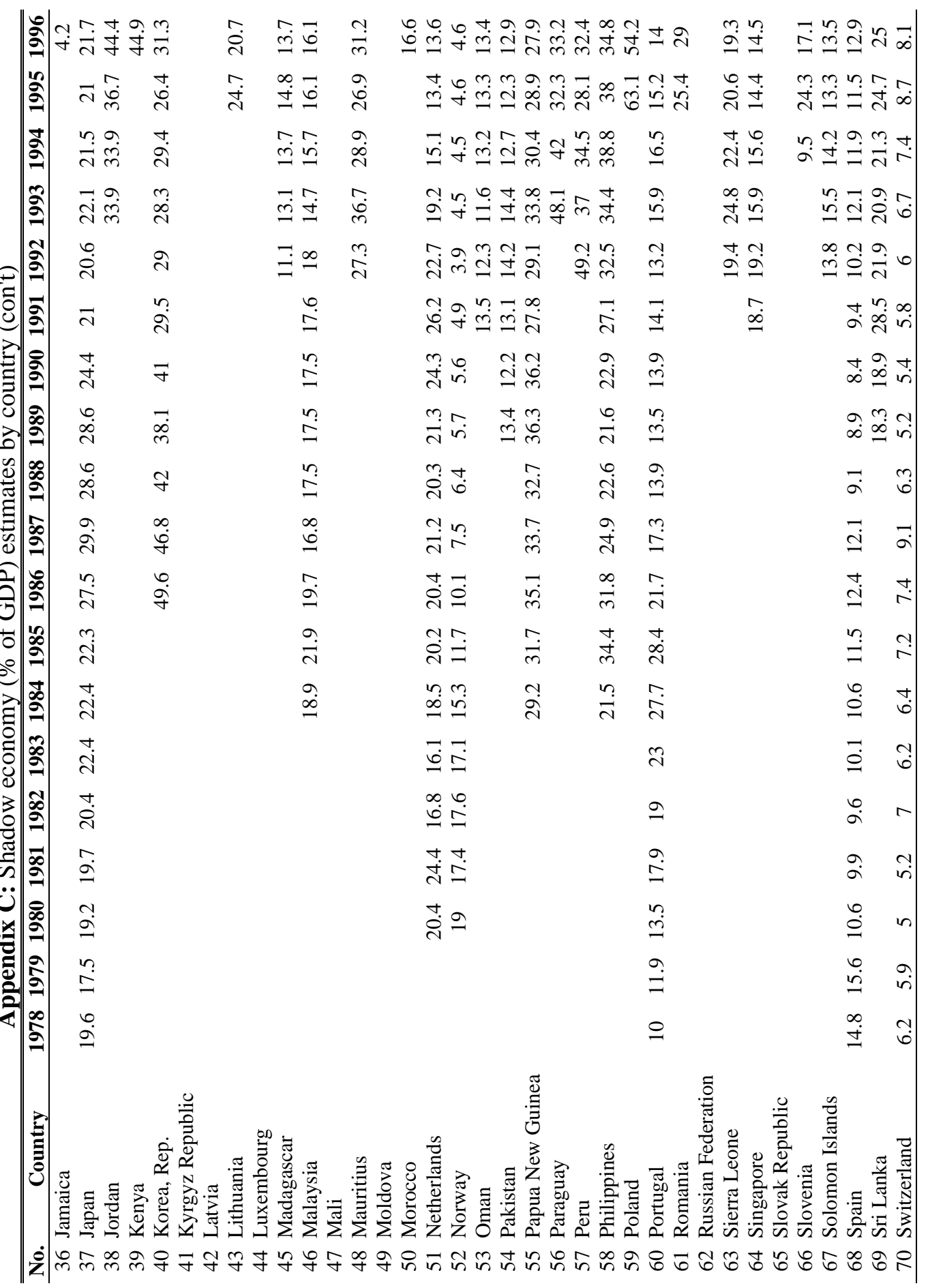




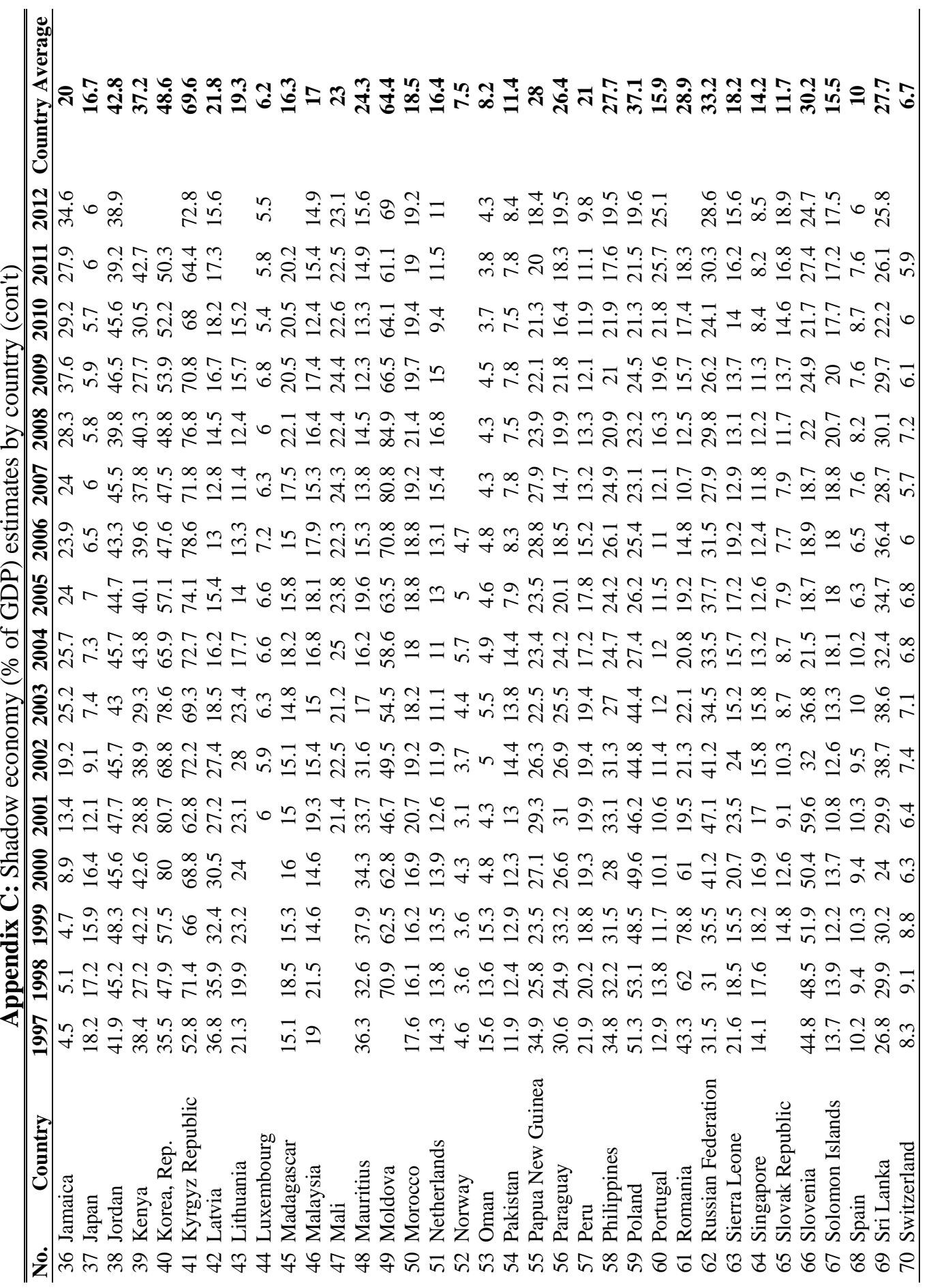




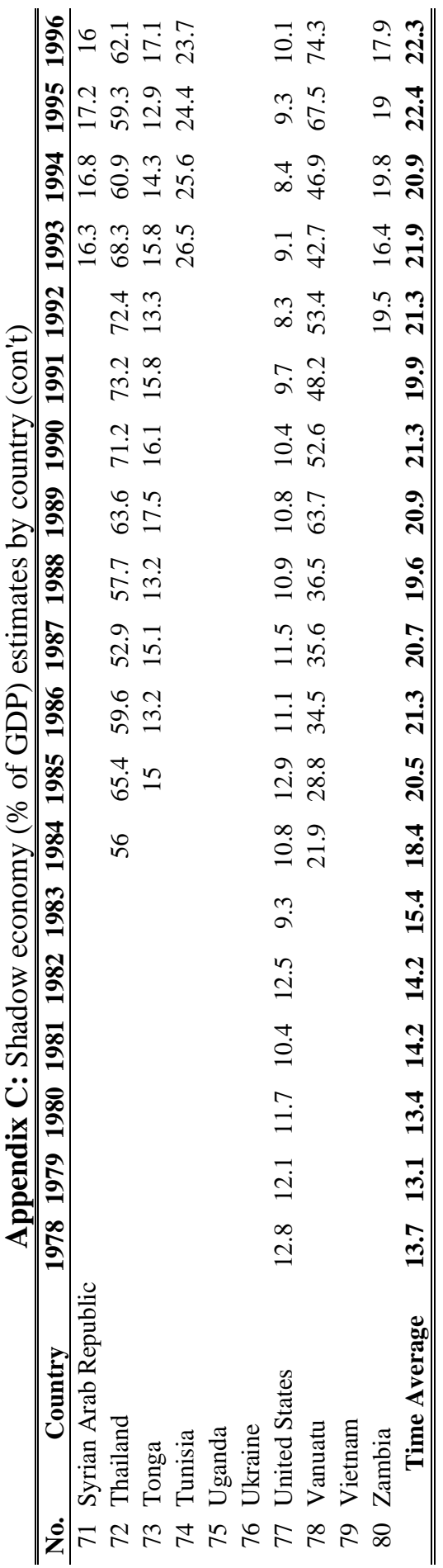




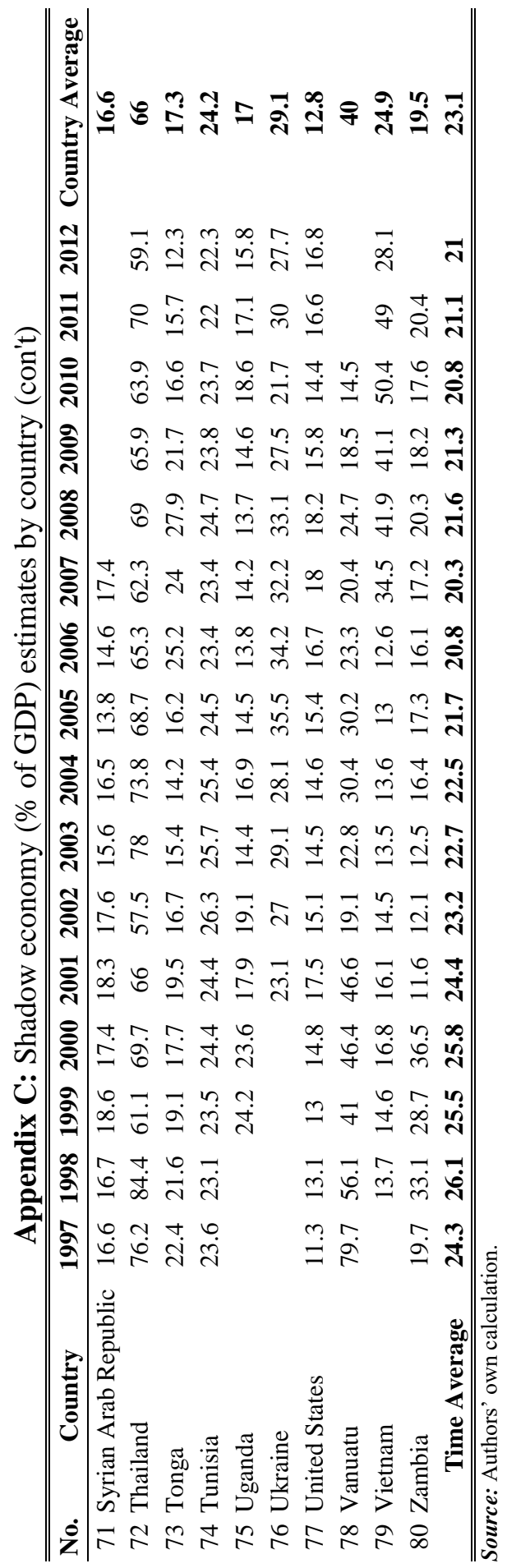

